\title{
ECOIOgy \\ Diversity and abundance of mosquitoes (Diptera, Culicidae) in a fragment of Amazon Cerrado in Macapá, State of Amapá, Brazil
}

\author{
Jose Ferreira Saraiva ${ }^{1 \bowtie}$, Ahana Maitra ${ }^{2 ®}$ \& Raimundo Nonato Picanço Souto ${ }^{3 \unrhd}$
}

\begin{abstract}
1. Instituto Nacional de Pesquisas da Amazônia-INPA, Departamento de Biodiversidade, Brazil. 2. Instituto Nacional de Pesquisas da Amazônia-INPA, Programa de Pós-Graduação em Genética, Conservação e Biologia Evolutiva, Laboratório de Genética de Mosquitos, Brazil. 3. Universidade Federal do Amapá, Laboratório de Arthopoda, Brazil.
\end{abstract}

\section{EntomoBrasilis 13: e901 (2020)}

\section{Edited by:}

Jeronimo Augusto Fonseca Alencar

Article History:

Received: 09.iii.2020

Accepted: 06.ix.2020

Published: 07.xi.2020

Corresponding author:

Jose Ferreira Saraiva

乃 jfsento@gmail.com

\section{Funding agencies:}

¿ Secretaria de Ciência e Tecnologia

do Estado do Amapá - SETEC-AP

\begin{abstract}
The Neotropical region has the highest diversity of species, but despite this diversity, this region presents many sampling gaps. The objective of this study was to study the diversity of the mosquitoes of family Culicidae (Diptera: Culicomorpha) as well as to identify the mosquito vectors, in a fragment of Amazon Cerrado in Macapá, Amapá. Three collection methods (Shannon trap, CDC and active collection) were used, and the samples were collected between January to December 2006. 21 species were identified; 11 of them being vectors of malaria, dengue fever, yellow fever, Zika, chikungunya and filariasis; and three of them, Toxorhynchites $h$. haemorrhoidalis (Fabricius), Wyeomyia melanocephala Dyar \& Knab and Wyeomyia aporonoma Dyar \& Knab were recorded for the first time from Amapá. The present study contributes to the diversity of mosquitoes (Culicidae) that can be used in additional mapping studies to mitigate epidemic outbreaks in the state of Amapá. Keywords: Arbovirus; malaria; mosquitoes; richness of species; Toxorhynchites haemorrhoidalis.
\end{abstract}

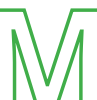

osquitoes of family Culicidae(Diptera: Culicomorpha) are monophyletic and classified into two subfamilies: Anophelinae and Culicinae (HARBACH \& KITCHING 2005). Culicidae comprises 3,578 recognized species worldwide, distributed among 42 genera and 140 subgenera ( $\mathrm{HARBCH}$ 2013) with a higher species diversity in the Neotropical region 1,069 species (31\%), distributed in 24 genera (RUEDA 2008). Brazil possesses more than half of this diversity, with 516 described species (WRBU 2018). Although there is a large diversity in the Neotropical region, many sampling gaps still exist. Moreover, recent molecular studies have revealed the existence of several cryptic species complexes (RoSA-FreITAS et al. 1998; RUIz-Lopez et al. 2012).

Mosquitoes are the most notorious pathogenic transmitters for humans, such as malaria, dengue, Zika, viral encephalitis and lymphatic filariasis (LANE \& CROSSKEY 1993). In coastal areas or places with proximal breeding grounds, these insects cause great nuisance, hampering the development of real estates as well as tourism (LANE \& CROSSKEY 1993; RuedA 2008). However, despite their high species richness, only a small part of the mosquitoes actually transmits diseases (RUEDA 2008), for example, human malaria is transmitted only by species of Anopheles (De ArRuda et al. 1986; Lane \& CROSSKEY 1993). In Brazil, only Anopheles darlingi Root and Anopheles aquasalis Curry are considered important vectors of malaria (De ArRuda et al. 1986; Conn et al. 2002; GALARDo et al. 2007), other species are considered secondary vectors, and among them, Anopheles marajoara Galvão \& Damasceno is considered as an important vector in Macapá (Conn et al. 2002; GALARDo et al. 2007; BARBOSA \& Souto 2011). Among other vectors of important re-emerging arboviruses in Brazil, Aedes aegypti (Linnaeus) is considered as an important arboviral vector (FIGUeIREDo 2007; WeAVER \& ReISEN 2010) for dengue virus (DENV) (Simmons et al. 2012; Powell 2018), yellow fever virus (YFV) (JENTES et al. 2011), Chikungunya virus (CHIKV) (LePARCGofFART et al. 2014), Zika virus (ZIKV) (WHO 2017) and Mayaro virus (MAYV) (WHO 2017; WIGGINs et al. 2018).

In addition to their medical importance, mosquitoes also have ecological relevance as they participate in the trophic chain of other insects as well as of aquatic and terrestrial vertebrates (RUEDA 2008). Various species adopt diverse strategies for their proliferation and dispersion. Even though there are specific breeding sites for certain species of mosquitoes (Consoli \& OLIVEIRA 1994), they may use permanent or semi-permanent soil breeding sites, man-made or natural containers (palm bracts, leaves, tree holes, bromeliads and Heliconia spp.) with accumulated rainwater or accumulated water from other sources (LANE \& CRosskey 1993; Consoli \& Oliveira 1994). The purpose of the present study was to record the species diversity of Culicidae in a forest fragment of the Amazonian Cerrado, near the urban perimeter of Macapá, as well as to identify those of medical importance.

\section{MATERIAL AND METHODS}

Study sites. The study was carried out in the campus of Federal University of Amapá, in Macapá, State of Amapá, Brazil. The area studied was between the geographical coordinates $0^{\circ} 0^{\prime} 7.82^{\prime \prime} \mathrm{N} 51^{\circ} 4^{\prime} 54.63^{\prime \prime} \mathrm{W}$ to $0^{\circ} 0^{\prime} 8.38^{\prime \prime} \mathrm{N} 51^{\circ}$ $5^{\prime} 15.02^{\prime \prime} \mathrm{W}$ and $0^{\circ} 0^{\prime} 36.70^{\prime \prime} \mathrm{S} 51^{\circ} 4^{\prime} 59.62^{\prime \prime} \mathrm{W}$ to $0^{\circ} 0^{\prime} 36.32^{\prime \prime} \mathrm{S} 51^{\circ}$ $5^{\prime 2} 20.82^{\prime \prime} \mathrm{W}$, with an elevation of 8-19 m. The campus belongs to 
the morphoclimatic domain of Amazonian Cerrado, covering an area of $906,722.45 \mathrm{~m}^{2}$ (Figure 1). The predominant climate in Amapá is of equatorial feature with temperature ranging from $25^{\circ} \mathrm{C}$ to $30^{\circ} \mathrm{C}$ (AB'SABER 1977). The annual rainfall is high $(2,500 \mathrm{~mm}$ average), with the maximum rainfall between March - May $(2,112.9 \mathrm{~mm})$ and the minimum rainfall between September - November $(177.8 \mathrm{~mm})$. The relative annual humidity is $85 \%$ with the annual mean insolation of 2,200 hours (SUDAM 1984).

The area of study has a marked human impact due to local urbanization. The phytophysionomy of this area comprises four non-interconnected forest fragments, three of them being gallery forests, and a grassland in the northern portion (Figure 1). There is predominance of native plant species of Cerrado (Amazonic biome) such as Murucis (Byrsonima H.B.K.; Malpighiaceae, Malpighiales), Caimbe (Curatella americana Linnaeus; Dileniaceae, Dileniales), Umiri (Humiria A.St-Hil; Humiriaceae, Malpighiales), Miriti (Mauritia flexuosa Linnaeus and Mauritia carana Wallace; Arecaceae, Arecales) (Azevedo 1969), as well as bromeliads and Heliconia spp., which are important for the propagation of some species of Culicidae (AlBıcócco et al. 2011). This area does not have permanent breeding sites, such as river backwaters or depressions of sluggish streams or rivers which favors the creation of mosquito species typical to such breeding sites, like Anopheles spp. However, the surrounding lowlying areas, locally know as hangover areas, mostly remain flooded due to riverine tides and rainfall (MACIEL 2001). The Igarapé Fortaleza is the closest, at a distance of $1.6 \mathrm{~km}$ from the campus. Moreover, there are 41 fish hatcheries and four treatment sewers (probable artificial breeding grounds) at $1.4 \mathrm{~km}$ and $1.2 \mathrm{~km}$ (straight line distance) respectively, from the campus. Figure 1 shows the distribution of these artificial breeding sites marked with white triangle signs.

Data collection. The monthly samples were collected for one year, between January to December 2006. Three sampling methods were used for three consecutive days: active collection, CDC (LANE \& CROSSKEY 1993) and Shannon trap (SHANNON 1939). The active collection was carried out through the capture of mosquitoes with entomological net and glass aspirator "pooter" (LANE \& CROSSkEY 1993). This collection was performed along a transect of Cerrado and gallery forest of length $100 \mathrm{~m}$ (Figure 1), between 07:0010:00 h. Periodic stops of five minutes were made during the course $(100 \mathrm{~m})$ of collection, facilitating the attraction and capture of mosquitoes. Light traps, such as two CDC traps, were installed at a distance of $200 \mathrm{~m}$ from each other, in the two largest forest fragments of the campus (Figure 1). The collections were carried out during the new moon phase, as the nights are darker, making the luminous attractions more effective (LANE \& CROSSKEY 1993). The CDC traps were installed at a height of $1.5 \mathrm{~m}$ from the ground at 18:00h and removed the next day at 07:00 h. Shannon's luminous trap was set inside the largest forest fragment, about $50 \mathrm{~m}$ from the edge (Figure 1). This trap was installed at $1800 \mathrm{~h}$ and withdrawn at 21:00 $\mathrm{h}$. The mosquitoes collected by active collection method, and by Shannon trap were separated as per their time of collection and subsequently analyzed for registering the hourly activity of the species collected.

The captured mosquitoes were stored inside plastic cups and labeled as per their time of collection (active collection and Shannon). The material was transported in a Styrofoam box to the Arthropod laboratory of the Federal University of Amapá (UNIFAP) and morphologically identified using the dichotomous keys of Consoli and Oliveira (1994). Forattini (2002), and LANE (1953). The terminologies, such as abbreviations of genera and subgenera, follow REINERT (2009).

All collected mosquitoes were deposited at the Zoological Collection of the Universidade Federal do Amapá - UNIFAP as voucher specimens and are available for future studies.

Data analysis. Sample rarefaction / extrapolation curves based on the sample size and sampling methods used were analyzed to compare the species richness and the diversity of nocturnal and diurnal species. Three Hill numbers (HILL 1973) were used in this study, which are associated with species richness estimators and their respective dominances. Hill numbers are diversity indices that quantify diversity in units of equivalent numbers of equally abundant species (HILL 1973; Colwell et al. 2004; Lou 2006; Gotelli \& ChaO 2013; ChaO et al. 2014). The first number $(q=0)$ analyzes the observed species richness, the second $(q=1)$ is the exponential value of the Shannon entropy index and, the third ( $q=2$ ) is the inverse Simpson index of dominance and measures the dominance of species (most abundant and prevalent species) in each sampling method (Colwell et al. 2004). This analysis was performed with iNEXT package (CHAO et al. 2014), using 1000 randomizations with 95\% confidence intervals. Subsequently, the abundance of the collected species was arranged per month and monthly precipitation to determine the temporal fluctuation of the species. All analyzes were performed in program R 3.5.0 (http://www.r-project.org/) (R CoRe TEAM 2018).

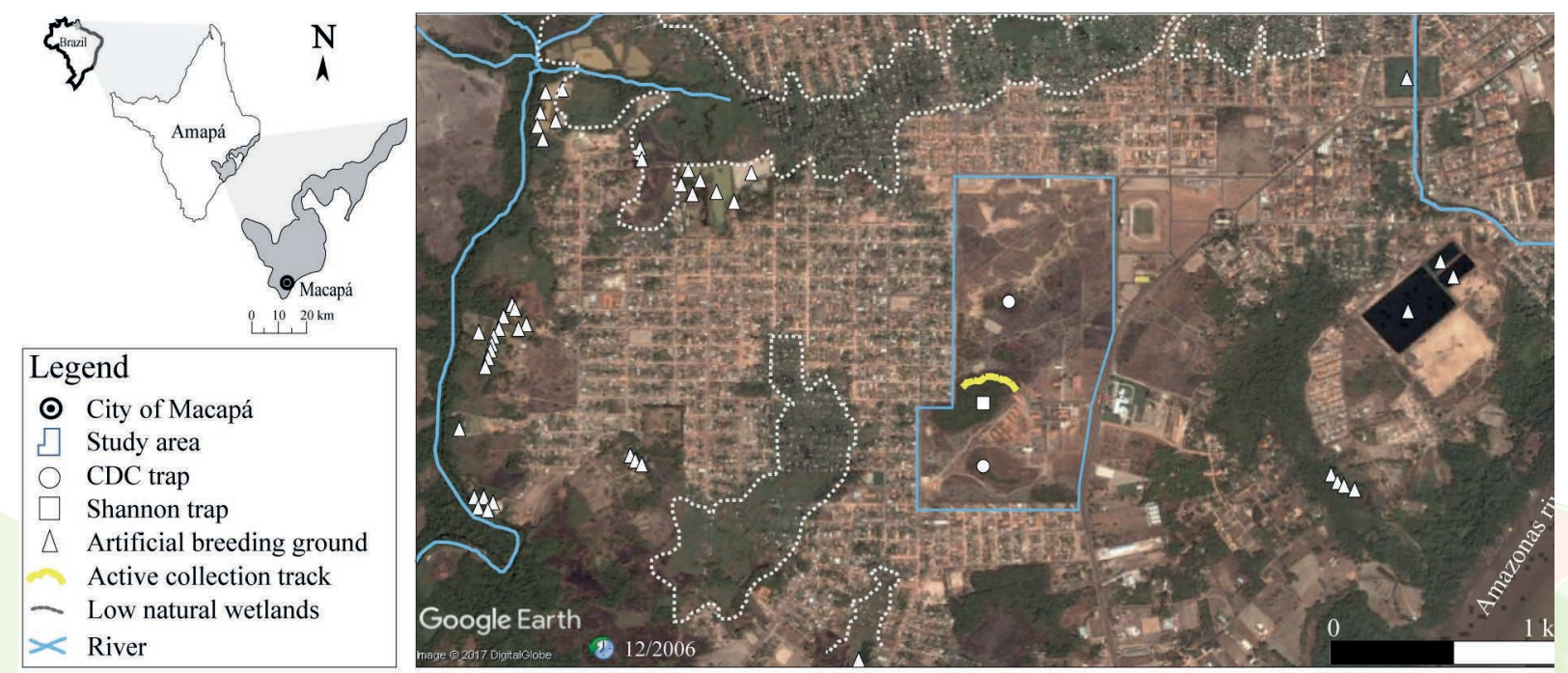

Figure 1. Study area on the campus of the Federal University of Amapá. The collection points are indicated (Shannon trap, CDC trap and Active Collection). The map also shows the artificial permanent breeding places near the study area, the transect used for active collection, low natural wetlands areas and rivers that allow creation of mosquitoes (Diptera: Culicidae). Adapted from Google Earth PRO (2015). 


\section{RESULTS}

Species composition. 1,918 mosquitoes were collected, corresponding to 21 species and 11 genera. Out of which, 642 were collected by Shannon trap, 460 by active collection and 816 by CDC trap (Table 1). The Shannon trap and CDC trap sampled 15 species each, where four species were collected exclusively with Shannon-trap and only one species was collected exclusively with CDC-trap. Active collection sampled 11 species, including the only specimen of Toxorhynchites haemorrhoidalis (Fabricius) (Table 1).

Rarefaction and extrapolation estimators for biodiversity (species richness $q=0$, Shannon entropy exponential $q=1$, and Simpson inverse concentration $q=2$ ) based on sample coverage, showed that our sampling was large enough to record the majority of Culicidae species in the study area. Diversity curves showed little gain in species richness, dominance, and equally common species in relation to increased sampling effort > 250 sampled units (Figure 2a).

The species richness recorded by each type of trap (Active $=11$, Shannon and CDC = 15), was close to the estimation observed in the rarefaction / extrapolation analysis, which is expected up to 12 species for active, 16 species for Shannon and 15 species for CDC. Therefore, a probable increase of $\sim 2$ to 3 species is expected if more collections are done in the study area (Figure $2 \mathrm{~b}$ ). The species richness among the three collection methods was statistically close to each other when compared to $>250$ individual units (Figure $2 b)$. The exponential Shannon entropy estimates $(q=1)$ also showed that the number of observed and predicted species was remarkably similar, indicating that the sampling included almost all equally common species. However, the number of common species was significantly lower in active

Table 1. List of mosquito species in the campus of the Federal University of Amapá, Macapá, Brazil. The species were recorded according to their method of collection, absolute number, and relative number of individuals during the period from January to December 2006.

\begin{tabular}{|c|c|c|c|c|c|}
\hline SPECIES & Shan & A.C. & CDC & $\mathbf{N}$ & $\%$ \\
\hline Aedeomyia (Aedeomyia) squamipennis (Lynch Arribálzaga) & 90 & 0 & 122 & 212 & 10.4 \\
\hline Aedes (Stegomyia) aegypti (Linnaeus) & 6 & 6 & 0 & 12 & 0.63 \\
\hline Aedes (Ochlerotatus) scapularis (Rondani) & 80 & 61 & 99 & 240 & 1.5 \\
\hline Aedes (Ochlerotatus) serratus (Theobald) & 43 & 38 & 109 & 190 & 9.91 \\
\hline Anopheles (Nyssorhynchus) braziliensis (Chagas) & 18 & 0 & 3 & 21 & 1.09 \\
\hline Anopheles (Nyssorhynchus) darlingi Root & 9 & 0 & 0 & 9 & 0.47 \\
\hline Anopheles (Nyssorhynchus) marajoara Galvão \& Damasceno & 20 & 0 & 0 & 20 & 1.04 \\
\hline Anopheles ( Nyssorhynchus) nuneztovari s.l. Galbadon & 7 & 0 & 0 & 7 & 0.36 \\
\hline Anopheles (Anopheles) mattogrossensis Lutz \& Neiva & 1 & 0 & 0 & 1 & 0.05 \\
\hline Coquillettidia (Rhynchotaenia) venezuelensis (Theobald) & 13 & 0 & 20 & 33 & 1.72 \\
\hline Culex (Culex) cf. nigripalpus Theobald & 190 & 138 & 260 & 588 & 30.7 \\
\hline Culex (Culex) quinquefasciatus Say & 65 & 18 & 60 & 143 & 7.46 \\
\hline Culex (Melanocolion) portesi Senevet \& Abonnenc & 27 & 0 & 30 & 57 & 2.97 \\
\hline Limatus durhamii Theobald & 0 & 62 & 18 & 80 & 4.17 \\
\hline Mansonia (Mansonia) titillans (Walker) & 48 & 0 & 55 & 103 & 5.37 \\
\hline Psorophora (Janthinosoma) ferox (Von Humboldt) & 25 & 76 & 21 & 122 & 6.2 \\
\hline Psorophora (Janthinosoma) amazonica Cerqueira & 0 & 25 & 7 & 32 & 1.67 \\
\hline Toxorhynchites (Lynchiella) haemorrhoidalis (Fabricius) & 0 & 1 & 0 & 1 & 0.05 \\
\hline Uranotaenia (Uranotaenia) hystera Dyar \& Knab & 0 & 0 & 6 & 6 & 0.31 \\
\hline Wyeomyia melanocephala Dyar \& Knab (Subgenus uncertain) & 0 & 22 & 2 & 24 & 1.25 \\
\hline Wyeomyia (Triamyia) aporonoma Dyar \& Knab & 0 & 13 & 4 & 17 & 0.89 \\
\hline TOTAL & 642 & 460 & 816 & 1,918 & - \\
\hline
\end{tabular}

*Shan: Shannon's trap. A.C.: Active Collection. CDC: automatic CDC light trap. $\mathrm{N}^{\circ}$ : absolute number of specimens collected and (\%): Relative frequency of the species in the sample. **Abbreviations of the genera and subgenera followed ReINERT (2009).

collection than with Shannon and CDC (Figure 2c). Also, the species dominance index estimated using Simpson's inverse concentration $(q=2)$ was slightly higher with Shannon. Although the difference between the 3 sampling methods was of the order of 0.5 'species', this difference was significant (Figure 2d).

Temporal variation of species. The three most abundant species observed were: Culex cf. nigripalpus Theobald (30.7\%), Aedes scapularis (Rondani) (12.5\%) and Aedeomyia squamipennis (Lynch-Arribálzaga) (10.4\%) (Table 1). The monthly collection of Culicidae, ranged from five species in the first month (January) to 17 species in June, the highest record in a single month's collection (Figure 3). When the richness of Culicidae was compared with the meteorological data obtained in this study, no significant correlation was found. However, the second semester of the year showed a greater variety of species than the first semester, except for
June, in which 17 species were collected (Figure 3).

The temporal fluctuations in the abundance of mosquito species are shown in Figure 3. There was a marked variation in the composition of species through the periods of high and low precipitation. For example: Ae. scapularis, Aedes serratus (Theobald), Psorophora ferox (Von Humboldt) and Psorophora amazonica Cerqueira, were more abundant at the beginning of the rainy season and decreased during the subsequent rainy months until they were absent in the driest month (September); Anopheles mattogrossensis Lutz \& Neiva and Uranotaenia hystera Dyar \& Knab, rare species, were also recorded during the rainy season. Anopheles nuneztovari s.l. was the only species which was observed to be highly abundant at the peak of driest period, while An. darlingi and An. marajoara (rare species) were more abundant in the collections from rainy months than dry months. On the other hand, Ad. squamipennis and Mansonia titillans (Walker) 
A

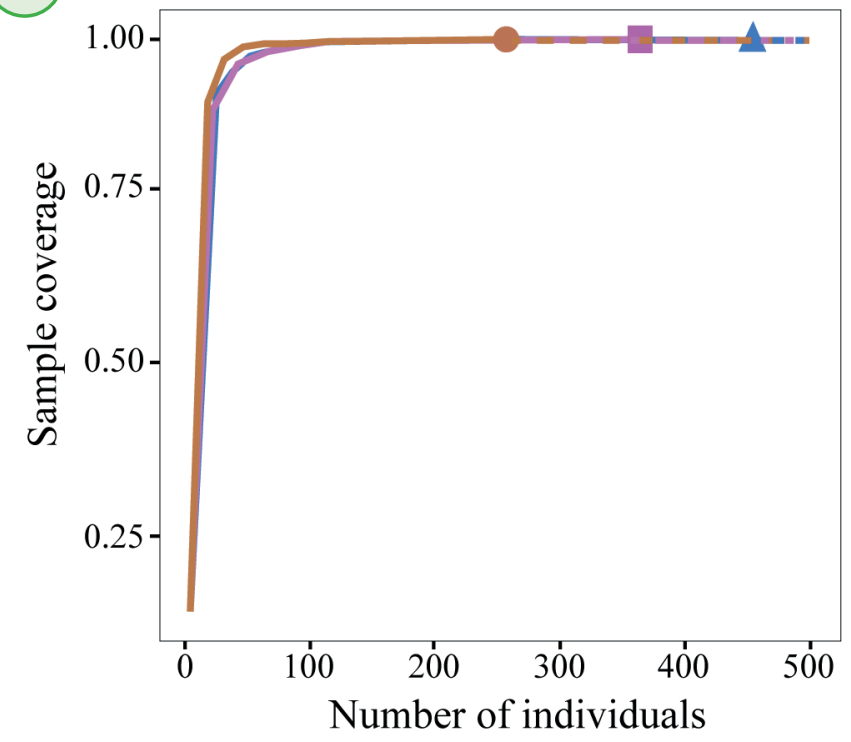

B

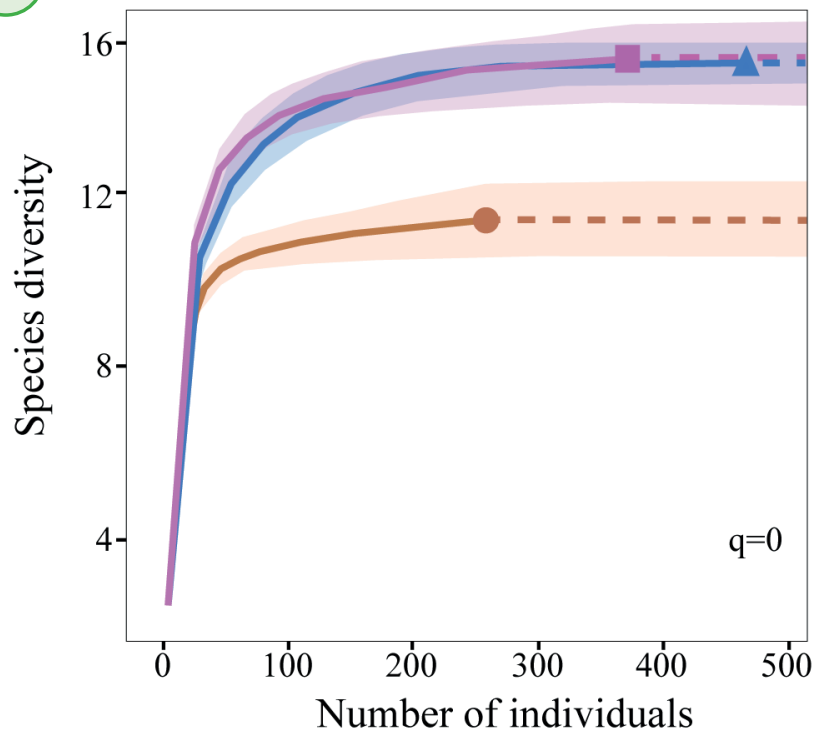

(c)

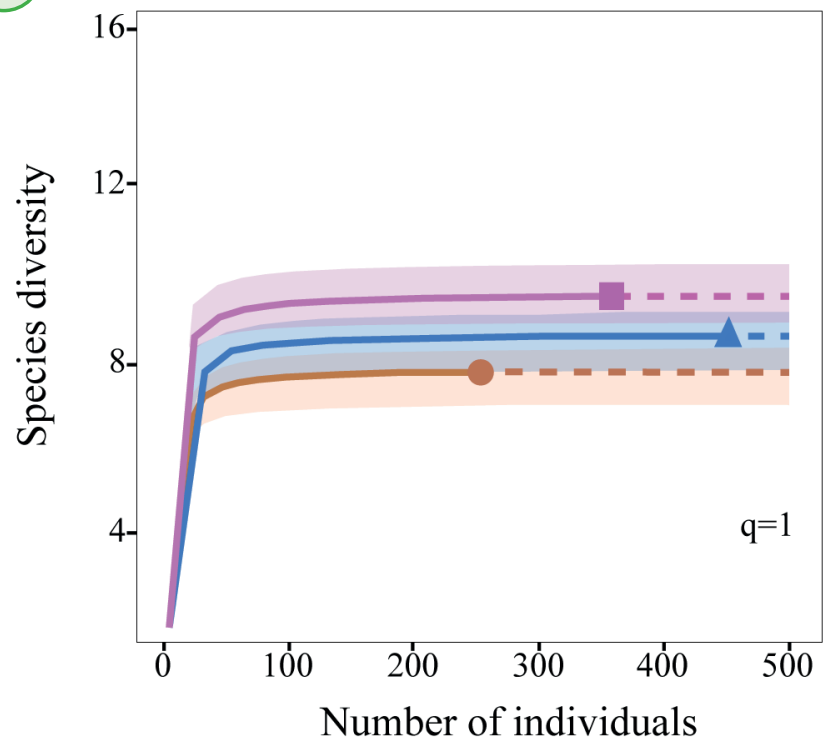

D

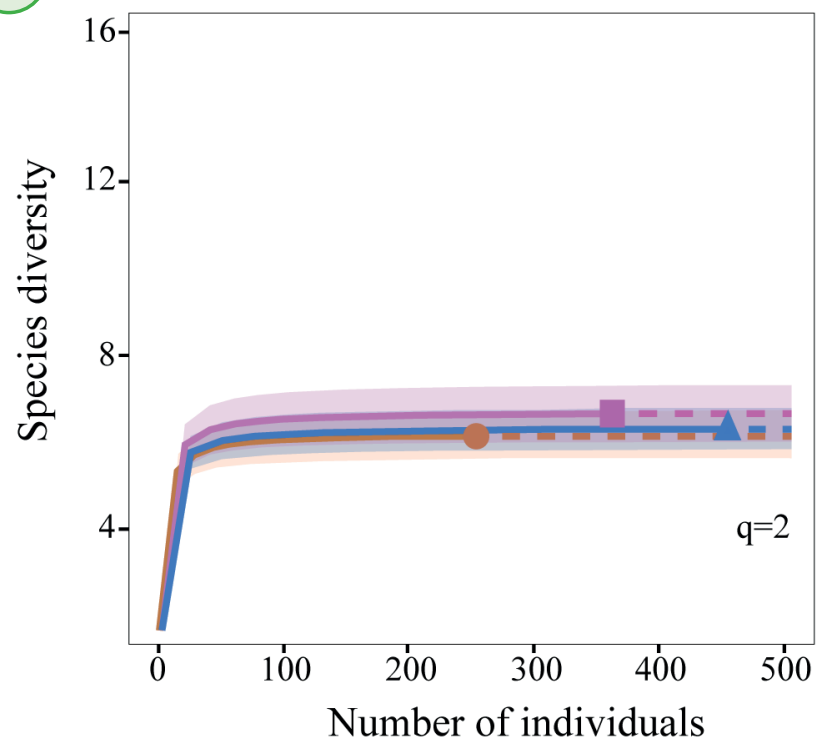

A.C.

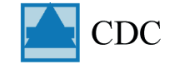

Shannon

interpolation

- - extrapolation

Figure 2. Rarefaction and extrapolation curves based on individual and coverage, based on Hill numbers $(q=0,1,2)$. A) Sample coverage; B) Species diversity, species richness $(q=0)$; C) Exponential of Shannon's entropy (Shannon diversity, $q=1$ ) and $\mathbf{D})$ Simpson's inverse concentration (Simpson diversity, $q=2$ ). The $95 \%$ confidence intervals (shaded) were obtained by bootstrapping $(1,000$ replications). Reference samples are indicated by solid shapes. The proposed estimators are accurate for both the rarefaction (solid line) and the shortrange extrapolation.

showed higher abundance at the end of rainy season and were reduced during the interval of dry and early rainy season. Coquillettidia venezuelensis (Theobald) did not show any seasonal pattern, except for being absent from the samples of January and March.

Species of medical importance. 11 species were classified as medically important, according to the CDC arbovirus catalog, available at https://wwwn.cdc.gov/arbocat/ (CDC 2018) (Table 2). The species of high epidemiological importance collected in the present study were: Ae. aegypti, An. darlingi and An. marajoara. However, these species were categorized as accidental species due to their less abundance in the studied area. Aedes aegypti $(n=12)$ was recorded from the collection of June to November, between 08:00 h and 10:00 h, and between 18:00 $\mathrm{h}$ and 19:00 $\mathrm{h} ;$ An. darlingi $(\mathrm{n}=9)$ was recorded in March and from June to October, between 18:00 h and 19:00 h; and An. marajoara $(\mathrm{n}=20)$ was collected in April, June, July, August, November and December, from 18:00 h - 20:00 h.

\section{DISCUSSION}

To date, a total of 95 species of mosquitoes had been recorded for the State of Amapá (Deane et al. 1948; Cerqueira 1961; TAdei et al. 1998; Póvoa et al. 2001; Souto \& Pimentel 2006; Bergo et al. 2007; GALARDo et al. 2007; Souto et al. 2011). In the present study, we studied the diversity of mosquitoes in a restricted area of Macapá (our study area) with different collection methods (CDC traps, Shannon traps and active collection). The findings of this study contribute to the knowledge of diversity of mosquitoes in Macapá, which in turn, may help other studies regarding the ecological and evolutionary processes of mosquitoes (RUEDA 2008).

Toxorhynchites (Fabricius) is the only non - hematophagous genus of Neotropical Culicidae. Its immature forms are predators of other mosquito larvae and small arthropods, and thus, considered as an option for the biological control of $A$. aegypti and Ae. albopictus larvae (RUEDA 2008; HutCHINGS 1994). 


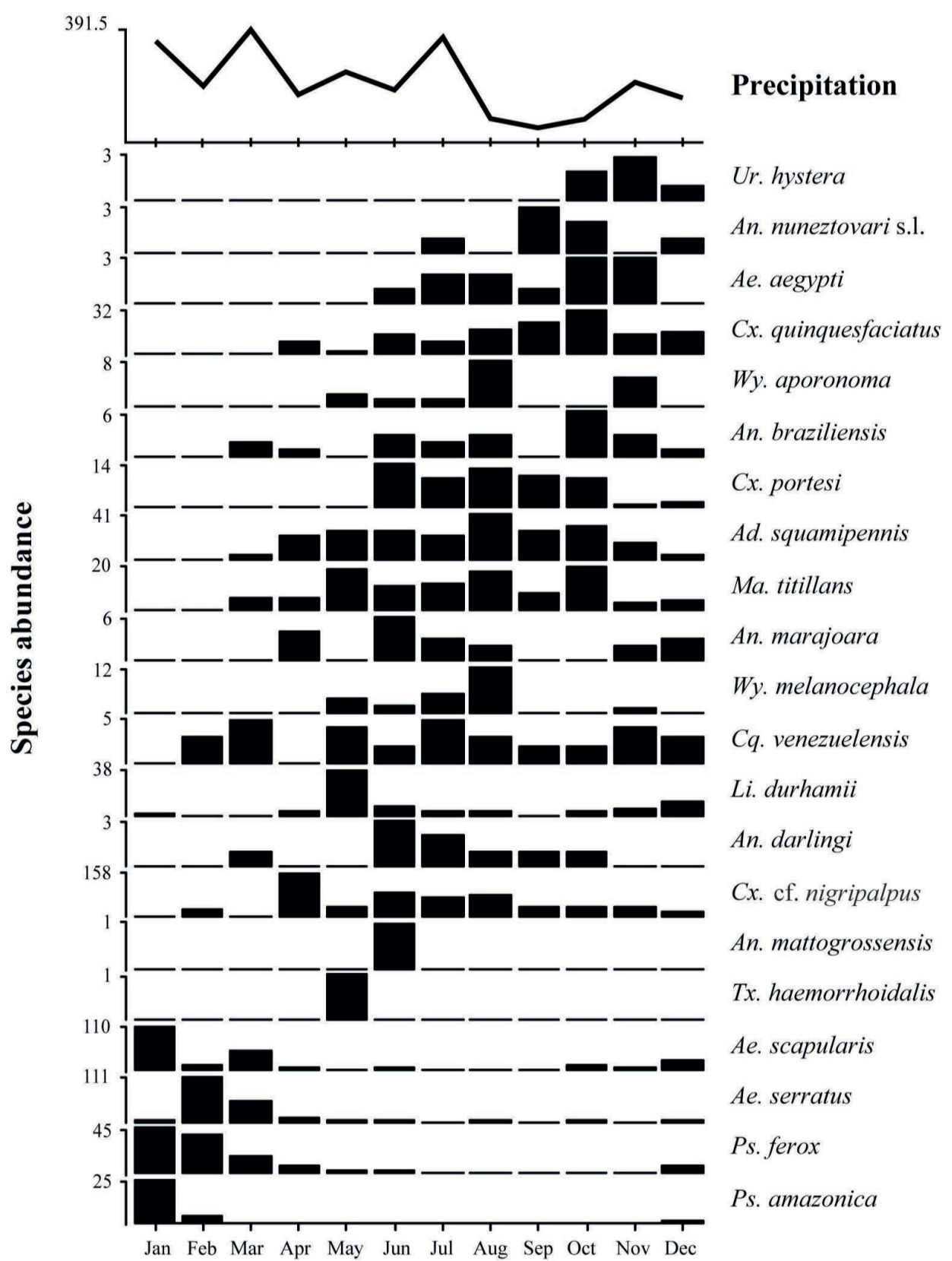

Figure 3. Abundance of species of Culicidae and relative monthly precipitation. The bars indicate the monthly relative abundance (y-axis is not standardized) and the line indicates the monthly precipitation over the sampled period. Precipitation levels were obtained from Núcleo de Hidrometeorologia e Energias Renováveis, Instituto de Pesquisas Científicas e Tecnológicas do Amapá - NHMET/IEPA.

Table 2. List of species of mosquitoes and associated diseases. The virus species are abbreviated according to CDC (2018).

\begin{tabular}{|c|c|}
\hline Species & Associated human diseases \\
\hline Aedeomyia squamipennis & GAMV \\
\hline Aedes aegypti & CHIK, DENV, YFV and ZIKV \\
\hline Aedes scapularis & ILHV, SLEV, VEEV, WYOV, YFV and W. bancrofti \\
\hline Aedes serratus & SLEV, VEEV and WYOV \\
\hline Anopheles darlingi & Malaria \\
\hline Anopheles marajoara & Malaria \\
\hline Anopheles nuneztovari s.l. & Malaria \\
\hline Coquillettidia venezuelensis & BSQV, CATUV, COTV, GMAV, MAYV, MURV and OROV \\
\hline Culex cf. nigripalpus & EEE, SLE and WNV \\
\hline Culex quinquefasciatus & SLE, WEE and $W$. bancrofti \\
\hline Mansonia titillans & VEE \\
\hline Psorophora ferox & CVV, EEEV, ORIV, SLEV, WNV and WYOV \\
\hline
\end{tabular}


Out of the nine species of Toxorhynchites, which are present in Brazil, Tx. $h$. haemorrhoidalis was confirmed in Amazonas and Pará, in addition to Cayenne, French Guiana. However, until the present study, Tx. h. haemorrhoidalis had not been reported in Amapá. A similar situation has been observed with Wy. melanocephala and Wy. aporonoma, as both of them have been recorded in the state of Pará and Amazonas (ConfalonierI \& Costa Neto 2012; Hutchings et al. 2013; Hutchings el al. 2018), but not in Amapá. The above scenario possibly demonstrates the lack of sufficient mosquito surveys in Amapá.

Culex cf. nigripalpus and Ae. scapularis are highly aggressive human blood feeders (ForatTINI 2002). Currently, CX. cf. nigripalpus is incriminated as a vector of equine encephalitis, St Louis Encephalitis and Wyeomyia virus. Adult females of Ad. squamipennis, the third most frequent species observed in this study, are ornithophilic but may accidentally bite humans (GABALDon et al. 1977; DÉGALLIER et al. 1992). Aedeomyia squamipennis is a vector of West Nile virus and Plasmodium spp., which infect birds (GABALDON et al. 1977). The last bird census in 2004 for this study area, registered 142 bird species, of which five were migratory birds (CAMPos et al. 2008). Hence, the large number of $A d$. squamipennis, collected in our study, may be related to the high diversity of birds in this campus. Moreover, migratory birds can pose a threat for arboviral outbreaks with the presence of Ad. squamipennis, because infected birds with West Nile virus bitten by these mosquitoes can consequently transmit the pathogens to the residents as well as the students on the campus (MARCONDEs et al. 2017).

Although the presence of main vectors of malaria were observed in the study area, the risk of transmission of malaria on campus may be low as a small number of vectors were actually collected. On the other hand, the risk of malaria transmission may be quite high in nearby neighborhoods due to their close proximity to favorable breeding sites and the high population density of these neighborhoods. BARBOSA \& Souto (2011) studied the ecological aspects of An. darlingi and An. marajoara, in two districts situated at the outskirts of Macapá (Bairro Zerão and Bairro Marabaixo I); one of which, the neighborhood Zerão, is the campus (our study area). The peak hourly activities observed by the authors is the same as recorded in this study for An. darlingi (between 18:30 $\mathrm{h}$ and 19:30 h), and An. marajoara (between 19:30 h and 20:30 h), while in Marabaixo I, peak activity for both species were between 19:30 $\mathrm{h}$ and 20:30 h.

This study reports the presence of three culicid species for the first time in Amapá and also makes a contribution towards the diversity of Culicidae in Macapá, Amapá. The presence of important mosquito vectors as observed in this study enforces the importance of similar surveys and recommends extensive mosquito surveillance activities in different ecosystems, to prevent and decrease the transmission of mosquito-borne diseases.

\section{ACKNOWLEDGEMENTS}

We thank the Federal University of Amapá for the permission to carry out mosquito collection on-campus and for the support extended by the Arthropod laboratory of the Biological Sciences Department. We are also grateful to the Secretaria de Ciência e Tecnologia do Estado do Amapá SETEC-AP, for the scientific initiation scholarship to Saraiva, J.F. We thank Rafael Homobono Naiff for the information provided regarding the census of birds in UNIFAP.

\section{REFERENCES}

Ab'saber, NA, 1977. Os domínios morfoclimáticos na América do Sul. Geomorfologia São Paulo, 52: 1-22.

Albicócco, AP, AE Carbajo \& D Vezzani, 2011. Mosquito community structure in phytotelmata from a South American temperate wetland. Journal of Vector Ecology, 36: 437-446. DOI: https://doi.org/10.1111/j.19487134.2011.00185.x

Azevedo, LG, 1969. Tipos Eco-Fisionômicos de vegetação do Território Federal do Amapá. Revista Brasileira de Zoologia, 32: 28-40.

Barbosa, LMC \& RNP Souto, 2011. Aspectos ecológicos de Anopheles (Nyssorhynchus) darlingi Root 1926 e Anopheles (Nyssorhynchus) marajoara Galvão \& Damasceno 1942 (Diptera: Culicidae) nos bairros Marabaixo I e Zerão, Macapá, Amapá, Brasil. Biota Amazônia, 1: 19-25. DOI: https://doi.org/10.18561/2179-5746/biotaamazonia. v1n1p19-25

Bergo, ES, RNP Souto, AKR Galardo, SS Nagaki, DC Calado \& MAM Sallum, 2007. Systematic notes on Anopheles Meigen (Diptera: Culicidae) species in the state of Amapá, Brazil. Memórias do Instituto Oswaldo Cruz,102: 373-3766. DOI: https://doi.org/10.1590/s0074-02762007005000053

CDC (Centers for Disease Control and Prevention), 2018 (CDC), Arbovirus catalog. Available on: <www.cdc.gov>. [Access in: 25.i.2019].

Campos, CEC, RH Naiff \& AS de Araujo, 2008. Censo de aves migratórias (Charadriidae e Scolopacidae) da Porção Norte da Bacia Amazônica, Macapá, Amapá, Brasil. Ornithologia, 3: 38-46.

Cerqueira, NL, 1961. Distribuição geográfica dos mosquitos da Amazônia. Revista Brasileira de Entomologia, 10: 111168.

Chao, A, NJ Gotelli, TC Hsieh, EL Sander, KH Ma, RK Colwell \& A Ellison, 2014. Rarefaction and extrapolation with Hill numbers: a framework for sampling and estimation in species diversity studies. Ecological Monographs, 84: 4567. DOI: https://doi.org/10.1890/13-0133.1

Colwell, RK, CX Mao \& J Chang, 2004. Interpolating, extrapolating, and comparing incidencelbased species accumulation curves. Ecology, 85: 2717-2727. DOI: https:// doi.org/10.1890/03-0557

Confalonieri, EU \& C Costa Neto, 2012. Diversity of mosquito vectors (Diptera: Culicidae) in Caxiuana, Para Brazil. Interdisciplinary Perspectives on Infectious Diseases, 2012: 1-8. DOI: https://doi.org/10.1155/2012/741273

Conn, JE, RC Wilkerson, MNO Segura, RT De Souza, CD Schlichting, RA Wirtz \& MM Povoa, 2002. Emergence of a new neotropical malaria vector facilitated by human migration and changes in land use. American Journal of Tropical Medicine and Hygiene, 66: 18-22. DOI: https://doi.org/10.4269/ajtmh.2002.66.18

Consoli, RA \& RLD Oliveira, 1994. Principais mosquitos de importância sanitária no Brasil. Editora Fiocruz, Rio de Janeiro.

De Arruda, M, MB Carvalho, RS Nussenzweig, M Maracic, AW Ferreira \& AH Cochrane, 1986. Potential vectors of malaria and their different susceptibility to Plasmodium falciparum and Plasmodium vivax in northern Brazil identified by immunoassay. American Journal of Tropical Medicine and Hygiene, 35: 873-881. DOI: https://doi.org/10.4269/ ajtmh.1986.35.873

Deane, LM, OR Causey \& MP Deane, 1948. Notas sobre a distribuição e a biologia dos anofelinos das regiões nordestina e amazônica do Brasil. Revista do Serviço Especial de Saúde Pública, 1: 827-965.

Dégallier, N, APA Travassos da Rosa, PFC Vasconcelos, JP Hervé, GC Sá-Filho, JFS Travassos da Rosa, ES Travassos da Rosa \& SG Rodrigues, 1992. Modifications of arbovirus transmission in relation to construction of dams in Brazilian Amazon. Ciência e Cultura, 44: 124-135.

Figueiredo, LTM, 2007. Emergent arboviruses in Brazil. Revista da Sociedade Brasileira de Medicina, 40: 224-229. DOI: https://doi.org/10.1590/s0037-86822007000200016

Forattini, OP, 2002. Culicidologia médica, Vol. 2: Identificação, 
Biologia e Epidemiologia. Editora da Universidade de São Paulo.

Gabaldon, A, G Ulloa \& N Godoy, 1977. Aedeomyia squamipennis (Diptera, Culicidae) vector natural de malaria aviaria en Venezuela. [Aedeomyia squamipennis (Diptera, Culicidae) natural vector of avian malaria in Venezuela]. Boletín de la Dirección de Malariología y Saneamiento Ambiental, 17: 9-13.

Galardo, AKR, M Arruda, AADA Couto, R Wirtz, LP Lounibos \& $\mathrm{RH}$ Zimmerman, 2007. Malaria vector incrimination in three rural riverine villages in the Brazilian Amazon. American Journal of Tropical Medicine and Hygiene, 76: 461-469. DOI: https://doi.org/10.4269/ajtmh.2007.76.461

Gotelli, NJ \& A Chao, 2013. Measuring and estimating species richness, species diversity, and biotic similarity from sampling data, pp. 195-211. In: Levin, SA (Editor-in-chief). Encyclopedia of Biodiversity (Second Edition). Elsevier. DOI: https://doi.org/10.1016/b978-0-12-384719-5.00424-x

Harbach, RE \& IJ Kitching, 2005. Reconsideration of anopheline mosquito phylogeny (Diptera: Culicidae: Anophelinae) based on morphological data. Systematics and Biodiversity, 3: 345-374. DOI: https://doi.org/10.1017/ s147720000500174x

Harbach, RE, 2013. Mosquito taxonomic inventory. MTI. UK. Available on: <www.mosquito-taxonomic-inventory.info/ valid-species-list>. [Access in 30.i.2019].

Hill, MO, 1973. Diversity and evenness: a unifying notation and its consequences. Ecology, 54: 427-432. DOI: https://doi.org/10.2307/1934352

Hutchings, RSG, 1994. Palm bract breeding sites and their exploitation by Toxorhynchites (Lynchiella) haemorrhoidalis haemorrhoidalis (Diptera: Culicidae) in an upland forest of the central Amazon. Journal of Medical Entomology, 31: 186-191. DOI: https://doi.org/10.1093/jmedent/31.2.186

Hutchings, RSG, RW Hutchings, IS Menezes, MDA Motta \& MAM Sallum, 2018. Mosquitoes (Diptera: Culicidae) From the Northwestern Brazilian Amazon: Araçá River. Journal of Medical Entomology, 55: 1188-1209. DOI: https://doi.org/10.1093/jme/tjy065

Hutchings, RSG, RWH Honegger \& MAM Sallum, 2013. Culicidae (Diptera: culicomorpha) from the central Brazilian Amazon: nhamundá and abacaxis rivers. Zoologia, 30: 1-14. DOI: https://doi.org/10.1590/s1984-46702013000100001

Jentes, ES, G Poumerol, MD Gershman, DR Hill, J Lemarchand, RF Lewis, JE Staples, O Tomori, A Wilder-Smith \& TP Monath, 2011. The revised global yellow fever risk map and recommendations for vaccination, 2010: consensus of the Informal WHO Working Group on Geographic Risk for Yellow Fever. The Lancet Infectious Diseases, 11: 622632. DOI: https://doi.org/10.1016/s1473-3099(11)70147-5

Lane, J, 1953. Neotropical Culicidae, Vol 1-2, São Paulo, Brazil.

Lane, RP \& RW Crosskey, 1993. Medical Insects and Arachnids. Springer Science Business media, London, UK.

Leparc-Goffart, I, A Nougairede, S Cassadou, C Prat \& X De Lamballerie, 2014. Chikungunya in the Americas. The Lancet, 383: 514. DOI: https://doi.org/10.1016/s01406736(14)60185-9

Lou, J, 2006. Entropy and diversity. Oikos, 113: 363-375. DOI: https://doi.org/10.1111/j.2006.0030-1299.14714.x

Maciel, N, 2001. Ressacas do Amapá: ecossistema úmido costeiro do Estado do Amapá. Diagnóstico preliminar Propostas de recuperação, preservação e uso sustentado. Secretaria de Estado do Meio Ambiente - SEMA/AP. vol. 2, Macapá.

Marcondes, CB, M Contigiani \& RM Gleiser, 2017. Emergent and reemergent arboviruses in South America and the Caribbean: why so many and why now? Journal of Medical Entomology, 54: 509-532. DOI: https://doi.org/10.1093/ jme/tjw209

Póvoa, MM, RA Wirtz, RNL Lacerda, MA Miles \& D Warhurst, 2001. Malaria vectors in the municipality of Serra do Navio, state of Amapá, Amazon Region, Brazil. Memórias do Instituto Oswaldo Cruz, 96: 179-184. DOI: https://doi.org/10.1590/s0074-02762001000200008

Powell, JR, 2018. Mosquito-borne human viral diseases: why Aedes aegypti? American Journal of Tropical Medicine and Hygiene, 98:1563-1565. DOI: https://doi.org/10.4269/ ajtmh.17-0866

R Core Team, 2018. R: A language and environment for statistical computing. $\mathrm{R}$ Foundation for Statistical Computing. Available on: <https://www.R-project.org/>.

Reinert, JF, 2009. List of abbreviations for currently valid generic-level taxa in family Culicidae (Diptera). European Mosquito Bulletin, 27: 68-76.

Rosa-Freitas, MG, R Lourenço-De-Oliveira, CJD CarvalhoPinto, C Flores-Mendoza \& TF Silva-Do-Nascimento, 1998. Anopheline species complexes in Brazil. Current knowledge of those related to malaria transmission. Memorias do Instituto Oswaldo Cruz, 93: 651-655. DOI: https://doi.org/10.1590/s0074-02761998000500016

Rueda, LM, 2008. Global diversity of mosquitoes (Insecta: Diptera: Culicidae) in freshwater. Hydrobiologia, 595: 477487. DOI: https://doi.org/10.1007/s10750-007-9037-x

Ruiz-Lopez, F, RC Wilkerson, JE Conn, SN McKeon, DM Levin, ML Quiñones, MM Póvoa \& YM Linton, 2012. DNA barcoding reveals both known and novel taxa in the Albitarsis Group (Anopheles: Nyssorhynchus) of Neotropical malaria vectors. Parasites \& Vectors, 5: 44. DOI: https://doi.org/10.1186/1756-3305-5-44

Shannon, RC, 1939. Methods for Collecting and Feeding Mosquitoes in Jungle Yellow Fever Studies 1. American Journal of Tropical Medicine and Hygiene, 1: 131-140. DOI: https://doi.org/10.4269/ajtmh.1939.s1-19.131

Simmons, CP, JJ Farrar, V Nguyen \& B Wills, 2012. Dengue. New England Journal of Medicine, 366: 1423-1432. DOI: https://doi.org/10.1056/nejmc1205584

Souto, RNP \& CHC Pimentel, 2006. Culicídeos (Diptera: Culicidae) da Região dos Lagos nos Municípios de Amapá, Pracuúba e Tartarugalzinho, pp. 131-42. In: Costa Neto $\mathrm{SV}$, editor. Inventário biológico das áreas do Sucuriju e região dos lagos, no Amapá. Macapá-AP, Programa Probio do Instituto de Pesquisas Científicas e Tecnológicas do Amapá.

Souto, RNP, JF Saraiva, RM Ferreira \& LM Barbosa, 2011. Culicídeos (Diptera, Culicidae) da Coleção Entomológica do Instituto de Pesquisas Cientificas e Tecnológicas do Amapá. Biota Amazônia, 1: 60-65. DOI: https://doi. org/10.18561/2179-5746/biotaamazonia.v1n2p60-65

SUDAM, 1984. Projeto de Hidrologia e Climatologia da Amazônia - Atlas Climatológico da Amazônia Brasileira, Belém.

Tadei, WP, BD Thatcher, JM Santos, VM Scarpassa, IB Rodrigues \& MS Rafael, 1998. Ecologic observations on anopheline vectors of malaria in the Brazilian Amazon. American Journal of Tropical Medicine and Hygiene, 59: 325-335. DOI: https://doi.org/10.4269/ajtmh.1998.59.325

Weaver, SC \& WK Reisen, 2010. Present and future arboviral threats. Antiviral Research, 85: 328-345. DOI: https://doi.org/10.1016/j.antiviral.2009.10.008

WHO (World Health Organization), 2017. Zika situation report. Situation report zika virus, microcephaly and GuillainBarre syndrome. WHO.

Wiggins, K, B Eastmond \& BW Alto, 2018. Transmission potential of Mayaro virus in Florida Aedes aegypti and Aedes albopictus mosquitoes. Medical and Veterinary Entomology, 32: 436-442. DOI: https://doi.org/10.1111/ mve.12322

WRBU (Walter Reed Biosystematics Unit), 2018 - Systematic catalog of Culicidae. Smithsonian Institution, Silver Spring USA. Available on: <www.mosquitocatalog.org>. [Access in: 24.viii.2019].

$\star \star * \star * * * * * \star$ 


\section{Suggestion citation:}

Saraiva, JS, A Maitra \& RNP Souto, 2020. Diversity and abundance of mosquitoes (Diptera, Culicidae) in a fragment of Amazon Cerrado in Macapá, State of Amapá, Brazil. EntomoBrasilis, 13: e901.

Available in: doi: 10.12741/ebrasilis.v13.e901
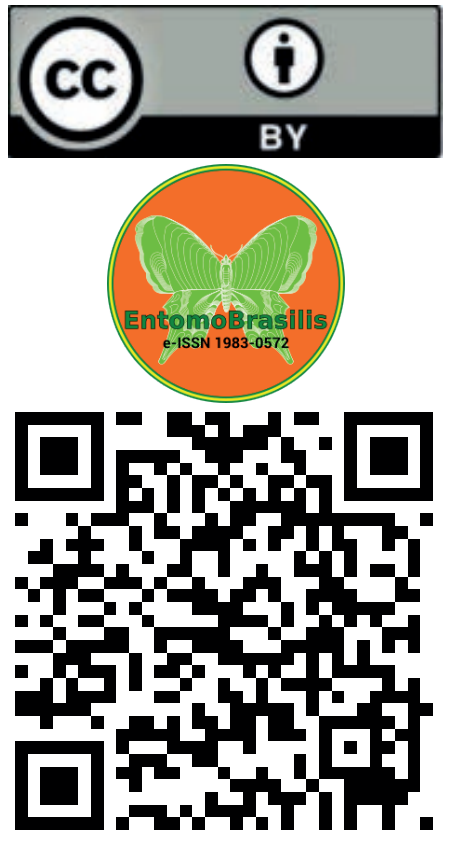